\section{A CHECKLIST OF BUTTERFLIES OF THENGUMARAHADA IN THE NILGIRIS, SOUTHERN INDIA}

\section{K. Cyril Rufus ${ }^{1,3}$ and S.P. Sabarinathan ${ }^{2}$}

1,2 Salim Ali Centre for Ornithology and Natural History, Anaikatty P.O., Coimbatore, Tamil Nadu 641108, India

${ }^{3}$ (Presently) 26/12 Kongurar Layout, Near Elayamuthur Pirivu, Udumalpet, Tamil Nadu 642126, India

Email: ${ }^{1}$ cyril4112@yahoo.co.in, ${ }^{2}$ sabarisacon@gmail.com

Thengumarahada is the largest among the seven tribal villages found in the Moyar valley belonging to the Nilgiris district, Tamil Nadu with an area of 500acres. Moyar valley is an ecologically strategic junction where the Western Ghats and Eastern Ghats meet. The village lies on the banks of the river Moyar. The study was carried out for one year during May 2005-April 2006.

The vegetation of the area includes deciduous and thorn forests comprising various plant species including Albizzia amara, Bauhinea racemosa, Capparis deciduas, Cassia auriculata, Chloroxylon swietenia, Dalbergia lanceolaria, Ficus benghalensis, Lantana camara, Mangifera indica, Syzygium cuminii, Tamarindus indica, Terminalia arjuna and cultivated areas include Oryza sativa, Musa paradisiaca, Calendula officinalis, Areca catechu and Cocos nucifera.

Pollard walk method was adapted for observing the butterflies following Moore (1975); Pollard et al. (1975); Walpole \& Sheldon (1999). The butterflies were observed during sunny day hours (0700-1200hr). We identified the butterflies using field guides by Wynter-Blyth (1957); Kunte (1997) and followed the classification in Gaonkar (1997)

In the study, 85 butterflies belonging to five families were recorded (Table 1). Among the families, the Nymphalidae were dominant with 35 species followed by Pieridae (16 species), Lycaenidae (14), Papilionidae (12) and Hesperiidae (8).

Eight endemic species were seen in the study area. Six species are listed in the Wildlife (Protection) Act, 1972 (Anon.,1990) with two species in Schedule I, four species in Schedule II and one species in Schedule IV. Danaid eggfly, Hypolimnas misippus is listed in Schedules I and II.

\section{REFERENCES}

Anonymous, (1990). The Indian Wildlife Act (Protection), 1972. Nataraj Publishers. Dehradun, 86pp.

Gaonkar, H. (1996). Butterflies of The Western Ghats, India, Including Sri Lanka: A Biodiversity Assessment of a Threatened Mountain System. Report submitted to the Centre for Ecological Sciences. Bangalore, $51 \mathrm{pp}$. (Unpublished).

Kunte, K. (2000). Butterflies of Penisular India. Universities Press. Hyderabad, 254pp.

Moore, N.W. (1975). Butterfly transects in a linear habitat, 1964-1973. Entomologist's Gazeteer 26: 71-78.

Pollard, E., D.O. Elias, M.J. Skelton \& J.A. Thomas (1975). A method of assessing the abundance of butterflies in Monk's Wood National Nature Reserve in 1973. Entomologist's Gazeteer 26: 79-88.

Walpole, M.J. \& I.R. Sheldon (1999). Sampling butterflies in tropicalrain forest: an evaluation of transect walk method. Biological Conservation 87: 85-91.

Wynter-Blyth, M.A. (1957). Butterflies of The Indian Region. Bombay Natural History Society, Bombay, 523pp.
Table 1. Butterflies of Thengumarahada in the Nilgiris, southern India

\begin{tabular}{|c|c|c|c|}
\hline Common Name & Scientific Name & ES & I W (P) Act \\
\hline \multicolumn{4}{|l|}{ Papilionidae } \\
\hline Tailed Jay & GraphiumagamemnonLinnaeus & & \\
\hline Five-Bar Swordtail & Graphium antiphates Cramer & & \\
\hline Common Jay & Graphium doson C \& R Felder & & \\
\hline Common Bluebottle & Graphium sarpedon Linnaeus & & \\
\hline Common Rose & Pachliopta aristolochiae Fabricious & & \\
\hline Crimson Rose & Pachliopta hector Linnaeus & $\mathrm{SI}, \mathrm{SL}$ & Schedule I \\
\hline Common Mime & Papilio clytia Linnaeus & & \\
\hline Common Banded & Papilio crino Fabricious & $\mathrm{PI}, \mathrm{SL}$ & \\
\hline \multicolumn{4}{|l|}{ Peacock } \\
\hline Lime Butterfly & Papilio demoleus Linnaeus & & \\
\hline Blue Mormon & Papilio polymnestorCramer & $\mathrm{PI}, \mathrm{SL}$ & \\
\hline Common Mormon & Papilio polytes Linnaeus & & \\
\hline Southern Birdwing & Troides minos Cramer & $\mathrm{SI}$ & \\
\hline \multicolumn{4}{|l|}{ Pieridae } \\
\hline Pioneer & Anaphaeis aurota Fabricious & & \\
\hline Common Emigrant & Catopsilia pomona Fabricious & & \\
\hline Mottled Emigrant & Catopsilia pyranthe Linnaeus & & \\
\hline Common Gull & Cepora nerissa Fabricious & & Schedule II \\
\hline Nilgiri Clouded Yellow & Colias nilgiriensis C \& R Felder & WG & \\
\hline Crimson Tip & Colotis danae Fabricious & & \\
\hline Small Orange Tip & Colotis etrida Boisduval & & \\
\hline Common Jezebel & Delias eucharis Drury & & \\
\hline Common Grass Yellow & Eurema hecabeLinnaeus & & \\
\hline Spotless Grass Yellow & Eurema laeta Boisduval & & \\
\hline Three-Spot & Eurema blandaBoisduval & & \\
\hline \multicolumn{4}{|l|}{ Grass Yellow } \\
\hline Great Orange Tip & Hebomoia glaucippe Linnaeus & & \\
\hline White Orange Tip & Ixias marianne Cramer & & \\
\hline Yellow Orange Tip & Ixias pyrene Linnaeus & & \\
\hline Psyche & Leptosia nina Fabricious & & \\
\hline Common Wanderer & Pareronia valeria Cramer & & \\
\hline \multicolumn{4}{|l|}{ Nymphalidae } \\
\hline Tawny Coaster & Acraea violae Fabricious & & \\
\hline Angled Castor & Ariadne ariadne Linnaeus & & \\
\hline Common Castor & Ariadne merione Cramer & & \\
\hline Joker & Byblia ilithyia Drury & & \\
\hline Common Map & Cyrestis thyodamas Evans & & \\
\hline Plain Tiger & Danaus chrysippus Linnaeus & & \\
\hline Striped Tiger & Danaus genutia Cramer & & \\
\hline Common Indian Crow & Euploea core Cramer & & Schedule IV \\
\hline Double-Branded Crow & Euploea sylvester Fabricious & & \\
\hline Common Baron & Euthalia aconthea Cramer & & \\
\hline Great Eggfly & Hypolimnas bolina Linnaeus & & \\
\hline Danaid Eggfly & Hypolimnas misippus Linnaeus & & Schedule I \& II \\
\hline Peacock Pansy & Junonia almana Linnaeus & & \\
\hline Yellow Pansy & Junonia hierta Fabricious & & \\
\hline Chocolate Pansy & Junonia iphita Cramer & & \\
\hline Lemon Pansy & Junonia lemonias Linnaeus & & \\
\hline Blue Pansy & Junonia orithya Linnaeus & & \\
\hline Common Treebrown & Lethe rohria Fabricious & & \\
\hline Common Evening & Melanitis leda Linnaeus & & \\
\hline \multicolumn{4}{|l|}{ Brown } \\
\hline Whitebar Bushbrown & Mycalesis anaxias Hewiston & & \\
\hline Gladeye Bushbrown & Mycalesis patnia Moore & & \\
\hline Common Bushbrown & Mycalesis perseus Fabricious & & \\
\hline Common Sailor & Neptis hylas Moore & & \\
\hline Nigger & Orsotrianea medus Fabricious & & \\
\hline Glassy Tiger & Parantica aglea Stoll & & \\
\hline Common Leopard & Phalanta phalantha Drury & & \\
\hline Common Nawab & Polyura athamas Drury & & \\
\hline Blue Tiger & Tirumala limniace Cramer & & \\
\hline Nilgiri Tiger & Parantica nilgiriensis Moore & $\mathrm{SI}$ & \\
\hline Common Threering & Ypthima asterope Klug & & \\
\hline Common Fivering & Ypthima baldus Fabricious & & \\
\hline White Or Ceylon & Ypthima ceylonica Hewiston & & \\
\hline \multicolumn{4}{|l|}{ Fourring } \\
\hline Common Fourring & Ypthima huebneriKirby & & \\
\hline Baby Fivering & Ypthima philomela Linnaeus & & \\
\hline Common Beak & Libythea lepita Moore & & Schedule II \\
\hline \multicolumn{4}{|l|}{ Lycaenidae } \\
\hline Common Pierrot & Castalius rosimon Fabricious & & \\
\hline
\end{tabular}

Manuscript 1623; (C) ZOO; Date of publication 21 August 2007 Received 19 August 2006; Revised received 31 January 2007; Finally accepted 10 May 2007 


\begin{tabular}{llll}
\hline Common Name & Scientific Name & ES & I W (P) Act \\
\hline Gram Blue & Euchrysops cnejus Fabricious & & Schedule II \\
Indian Cupid & Everes lacturnus Godart & & \\
Grass Jewel & Freyeria trochylus Freyer & \\
Common Cerulean & Jamides celeno Cramer & \\
Dark Cerulean & Jamides bochus Cramer & \\
Zebra Blue & Leptotes plinius Fabricious & \\
Lime Blue & Chilades laius Stoll & \\
Quaker & Neopithecops zalmoraButler & \\
Common Line Blue & Prosotas nora C \& R Felder & \\
Pale Grass Blue & Psuedozizeeria mahaKollar & \\
Common Silverline & Spindasis vulcanus Fabricious & IS \\
Red Pierrot & Talicada nyseus Guerin-Meneville & \\
Tiny Grass Blue & Zizula hylax Fabricious & \\
Hesperiidae & & \\
Brown Awl & Badamia exclamationisFabricious & \\
Malabar Spotted Flat & Celaenorrhinus ambareesaMoore & WG \\
Common Spotted Flat & Celaenorrhinus leucocera Kollar & \\
Common Banded Awl & $\begin{array}{l}\text { Hasora chromus Cramer } \\
\text { Fulvous Pied Flat }\end{array}$ & \\
Common Small Flat & Sarangesa dasahara Moore & \\
Indian Skipper & Spialia galba Fabricious & \\
Rice Swift & Borbo cinnara Wallace & \\
\hline
\end{tabular}

IS - Indian Subcontinent; ${ }^{1}$ SI - Southern India; ${ }^{2} \mathrm{PI}$ - Peninsular India; WG Western Ghats; SL - Sri Lanka

1 Southern India includes Tamil Nadu, Kerala, Karnataka, Andhra Pradesh, Goa and Maharashtra; ${ }^{2}$ Peninsular India includes all parts south of Central Indian Hills including Arvali, Vindhyas and Satpura

E S - Endemic Status; I W (P) Act - Indian Wildlife (Protection) Act 1972

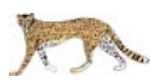

\section{Advertisement for the Post of Research Assistant}

As part of the UNDP Post Tsunami Environment Initiative Project, the Nature Conservation Foundation (NCF) in Mysore is on the lookout for three research assistants.

Background: The component of the above project being handled by NCF is aimed at the characterization of fisheries along the Coromandel coast with the main emphasis being on the trawl fishing sector.

Eligibility Criteria:

- Fluent in English and Tamil

- Msc in Fisheries, Marine Science, Wildlife Science, Environmental Science or any other life science.

- License for two and/or four wheelers.

- Computer operational skills (MS Office)

- Good taxonomic skills for the identification of various marine species

- Good Public Relations skills will be an added asset.

Study area: Coromandel coast of Tamil Nadu (Pulicat to Point Calimere)

Fieldwork will include:

- Regular monitoring of the catch and bycatch of trawlers at selected trawler/fish landing sites along the study area.

- Interviewing fishermen

- You will occasionally be required to accompany trawlers for the onboard quantification.

Selected candidates will be paid a monthly amount of Rs. 7000. Actuals and other project related expenses will be covered by the project.

Interested candidates please email your CV to

Mr. Aaron Lobo <aaronlobo@ncf-india.org>

Mobile: +919840854261 or

Dr. Rohan Arthur <rohan@ncf-india.org>

\section{Bombay Natural History Society (BHNS)}

requires personnel for the following posts:

1. Information Officer for its Environmental Information System (ENVIS) Centre (one post)

Essential Qualification: M.Sc (Wildlife/Zoology/Environmental Sciences). Candidates with wildlife/ornithology back ground will be preferred.

Job description: Handling database - Avian ecology and Inland wetlands, Maintenance of database; Technical support for Newsletter publication and website maintenance; Co-ordination with library; Assisting the Scientist In-charge ENVIS in processing of queries.

Location: the post is based in Mumbai Head Office.

Age Limit: Upto 30 years.

Salary: Rs. 1, 34,400/- per annum on CTS basis.

The appointment will be initially for a period of 1 year on contract basis.

\section{Systematic Botanist \& Taxonomist (one post)}

Educational Qualification: Candidate should be B.Sc. (with minimum 3 years experience in field work) or M.Sc or preferably Ph.D in Botany. The candidate should have knowledge in general practices followed in plant collection, collection of data, collation and retrieval systems and should be well-versed with different systems of plant classification and herbarium technologies. The candidate is expected to spend many days in the field and he/she should be physically fit and healthy.

Salary: Rs. 2, 16,000/- per annum in CTS basis.

Age Limit: Upto 30 years.

Candidates fulfilling the above requirement may send their application with detailed biodata and passport size photograph superscribing the envelope the post applied for within 15 days to the Director, Bombay Natural History Society, Hornbill House, Shaheed Bhagat Singh Road, Mumbai 400 023. Website: for more details contact our website www.bnhs.org.

\section{Associate Officer (IBA) - one post}

The Important Bird Area (IBA) Programme aims to identify, document and advocate the protection and management of a network of sites that are important for the long-term viability of naturally occurring bird populations across the geographic range of those bird species for which a site-based approach is appropriate.

Qualification: Postgraduate/Graduate in Wildlife/Ecology/Biological Sciences/Environmental Science/Geography

Experience: 1-2 years experience in the field of avian ecology/ nature conservation, experience in gathering and analyzing field data and knowledge of Geographical Information Systems (GIS) will be an advantage. (Fresher with good knowledge of ecology especially birds may also apply).

\section{Educational Assistant for Conservation Education Centre} (CEC - Delhi) - one post

As part of Conservation Education Programmes, BHNS has established a Conservation Education Centre with the financial assistance of Government of Delhi at Asola Bhatti Wildlife Sanctuary in New Delhi. The Centre has been creating awareness about biodiversity conservation among children and adults through variety of field education programmes.

Qualification: Postgraduate/Graduate in Environmental Science/ Wildlife/Ecology/Biological Sciences/Social Sciences

Experience: 1-2 years experience in the field of environment education or experience of teaching environmental studies in school/ college. The post holder needs to be a good communicator and fluent in English and Hindi.

The appointment will be on contractual basis and salary will be commensurate with experience, skills and background. Interested candidates may apply by August 14, 2007 with bio-data and details regarding expected salary and three references to Director, Bombay Natural History Society, Hornbill House, Shaheed Bhagat Singh Road, Mumbai 400023.

Please mention the name of the post applied for on the envelope. 